\title{
As múltiplas dimensões presentes no exercício profissional do assistente social: intervenção e o trabalho sócio-educativo
}

\author{
The multiple present dimensions in the social worker professional exercise: intervention \\ and the social-educational work
}

Mabel Mascarenhas Torres*

\begin{abstract}
Resumo:
Este artigo tem por objetivo analisar - por meio de uma breve revisão de literatura as múltiplas dimensões constitutivas do exercício profissional do assistente social, focando o trabalho sócio-educativo como uma das possibilidades de concretização do trabalho deste profissional. Os autores estudados indicam que o Serviço Social é uma profissão cuja marca interventiva o particulariza dentre as demais profissões inscritas na divisão sócio-técnica do trabalho. $O$ trabalho sócio-educativo é uma das formas de concretização do trabalho do assistente social. Este tipo de trabalho tem sido requisitado aos profissionais que atuam nas mais diversas áreas, quer seja na esfera pública como na esfera privada. É um trabalho balizado pelo planejamento e execução compartilhados entre os sujeitos envolvidos, cuja relação de saber e poder está a serviço da população usuária dos serviços prestados via rede socioassistencial.
\end{abstract}

Palavras-chave: Exercício profissional do assistente social; Trabalho sócioeducativo; Processos de trabalho.

\begin{abstract}
This article treats of the multiple constituent dimensions of the social worker professional exercise, about the social-educational work as one of the possibilities of materialization of this professional's work. The Social Work is recognized as profession whose marks intervene it qualifies and it differentiates of the other professions of the social area. The social-educational work has been requested the professionals that act in the most several areas, he wants it is in the public sphere as in the private sphere. Before the identified demands in your execution should not be analyzed without the recognition of the Social Work as profession and without analyzing the conditions for your effective.
\end{abstract}

Key words: Social worker professional exercise - work; Social-educational;- work processes

\footnotetext{
*Assistente Social, doutora em Serviço Social pela PUC-SP, professora adjunta do Departamento de Serviço Social da Universidade Estadual de Londrina.
} 


\section{Introdução}

Este artigo tem por objetivo analisar - por meio de uma breve revisão de literatura as múltiplas dimensões constitutivas do exercício profissional do assistente social, focando o trabalho socioeducativo como uma das possibilidades de concretização do trabalho desse profissional. Por meio de uma breve revisão da literatura identificada no Serviço Social a partir dos anos 1980 , foi possível identificar o modo como problematizam o início da profissão, a sua dimensão interventiva, a discussão sobre o trabalho desenvolvido pelo assistente social. Ao final, sinalizo o trabalho socioeducativo como uma das possibilidades interventivas do exercício profissional do assistente social, cuja referencia teórico-metodológica é a matriz crítica presente no Serviço Social na contemporaneidade.

O trabalho socioeducativo tem sido requisitado aos profissionais que atuam nas mais diversas áreas, quer seja na esfera pública, quer na esfera privada. Diante das exigências identificadas na sua execução, não deve ser analisado sem o reconhecimento do Serviço Social como profissão e sem analisar as condições para sua efetivação. Consultando a legislação social vigente no país, a Lei Orgânica da Assistência Social, lei no 8.742, de 7/12/1993, o Estatuto da Criança e do Adolescente, lei no 8.069, de 13 de julho de 1990, a Política Nacional da Assistência Social, e as demais, o trabalho socioeducativo é enfocado como uma das possibilidades de acompanhamento do desenvolvimento das famílias atendidas na rede socioassistencial. Os exemplos são diversos, destacando os programas de transferência de renda (em todas as esferas), o acompanhamento aos adolescentes que cumprem medidas socioeducativas, entre outros. O trabalho socioeducativo está circunscrito como uma das prerrogativas do trabalho social operacionalizado nos Centros de Referência da Assistência Social, a saber: "serviços sócioeducativos para crianças, adolescentes e jovens na faixa etária de 6 a 24 anos, visando à sua proteção, socialização e o fortalecimento dos vínculos familiares e comunitários". (PNAS, 2007, p. 181). O que se observa é que, ao realizar seu exercício profissional executando atividades por meio da prestação de serviços socioassistencias, ou mesmo, planejando e operacionalizando programas e projetos apensos às políticas públicas, é solicitado ao profissional o domínio desse tipo de trabalho, como uma perspectiva 
metodológica. Nesse sentido, os estudos na área são necessários a fim de colocar em debate o modo como os assistentes sociais realizam e reconhecem este tipo de trabalho.

\section{O Reconhecimento do Serviço Social como Profissão Circunscrita na Divisão Sociotécnica do Trabalho}

O Serviço Social é uma profissão inscrita na divisão sociotécnica do trabalho, regulamentada pela Lei no 8662 de 07 de junho de 1993, com alterações determinadas pelas resoluções CFESS no 290/94 e no 293/94, e balizada pelo Código de Ética, aprovado pela resolução CFESS no 273/93, de 13 de março de 1993.

Desde a sua origem, o Serviço Social é reconhecido como profissão; porém, recorrendo aos autores que estudam sua natureza, identifico várias formas de analisar tanto a origem como a sua constituição. Compartilho da análise construída por lamamoto e Carvalho (1983), cujo fundamento é a perspectiva sócio-histórica. Os autores afirmam que a origem do Serviço Social no Brasil, na década de 1930, está intrinsecamente associada à burguesia emergente, como uma estratégia da classe dominante para disciplinar e atenuar os males sociais advindos da expansão capitalista. A origem do Serviço Social é marcadamente histórica, e sua inserção na divisão sociotécnica do trabalho está intrinsecamente articulada às formas assumidas pelos embates da classe social subalterna com o bloco do poder no enfrentamento da questão social. A autora entende que esta inserção depende "ainda do caráter das políticas do Estado, que articuladas ao contexto internacional, vão atribuindo especificidades à configuração do Serviço Social na divisão social do trabalho" (IAMAMOTO, 1992, p. 87).

Sob esta perspectiva, o Serviço Social consolida-se como profissão na e a partir da divisão do trabalho, que "supõe inseri-la no conjunto das condições e relações sociais que Ihe atribuem um sentido histórico e nas quais se torna possível e necessária". (IAMAMOTO, 1992, p. 88). Ou seja, para compreender e reconhecer o Serviço Social como profissão, necessariamente é preciso analisá-lo sob sua vinculação à divisão do trabalho, à influência da Igreja Católica e sob as contradições identificadas na realidade social.

Com o desenvolvimento do capitalismo no Brasil, advém não somente o crescimento econômico, mas as contradições presentes nesse modo de produção, quais 
sejam, a propagação do capital, que traz com ela um quadro de fragilização das relações de trabalho, a competição acirrada entre as pessoas em busca de um lugar no mercado de trabalho, entre outras.

É neste contexto, em que se afirma a hegemonia do capital industrial e financeiro, que emerge sob novas formas a chamada 'questão social', a qual se torna base de justificação desse tipo de profissional especializado [...] É a manifestação, no cotidiano da vida social, da contradição entre o proletariado e a burguesia, a qual passa a exigir outros tipos de intervenção, mais além da caridade e repressão (IAMAMOTO; CARVALHO, 1983, p. 77).

Em contra partida, a expansão capitalista favorece a aliança da classe dominante com o Estado, fortalecendo a primeira e, ao mesmo tempo, enfraquecendo a organização da classe trabalhadora, especialmente no que se refere às suas lutas e reivindicações.

Historicamente, essa profissão "recebe" a marca da ajuda, e da solidariedade que permeiam as ações voltadas ao controle social e à erradicação da pobreza, principalmente, e/ ou especialmente, aquelas que são visíveis aos olhos da classe dominante. Nesse contexto, o Serviço Social assume parcela do trabalho que visa à reforma social e, portanto, a necessidade de efetivar ações na esfera psicossocial. Assim, os limites estabelecidos nessa ação decorrem daqueles que mantêm a sociedade capitalista e a ordem social vigente. Pode-se dizer que o Serviço Social colaborou substantivamente para reforçar o controle e a coerção exercidos pela classe dominante diante do crescimento acelerado da pobreza e da generalização da miséria. O controle era decorrente da ameaça à ordem social imposta pela classe dominante à classe trabalhadora e aos chamados "sobrantes" do processo produtivo. Vale dizer que a classe dominante produz esses agentes profissionais, influenciando de forma decisiva na construção do seu exercício profissional. Esta influência pode ser identificada na medida em que o Serviço Social vai, ao longo de sua história, assumindo o projeto ideológico da burguesia como viável para a manutenção da vida em sociedade. Buscava-se naquele momento uma base comum de conhecimento que pudesse dar sustentação ao exercício profissional desenvolvido pelos assistentes sociais que compartilhavam dessa concepção de profissão, uma vez que eram conclamados a construir respostas para os problemas sociais, além de apresentar alternativas que viabilizem sua permanência e importância, como profissão, no cenário nacional. 
Desde os primórdios da profissão, o trabalho desenvolvido pelos assistentes sociais é direcionado majoritariamente à população que vive em condição de vulnerabilidade social e em condição de pobreza. Excluída do processo produtivo, do acesso da produção de bens e serviços, essa população procura no assistente social o profissional que poderá ampará-la, orientá-la para que possa usufruir do bem-estar social. O assistente social atua em uma via de mão-dupla: mesmo entendendo que as expressões da questão social são o seu objeto de intervenção e matéria-prima do seu exercício profissional, predominam, nesse período inicial, ações dirigidas às questões que se voltam ao modo como os "clientes" vivem em seu meio social. Ao trabalhar nessa perspectiva, o profissional reforça a realização de atividades cujo rumo demarca a mudança de comportamento dos indivíduos e sua adequação para melhor inserção na ordem social; na justiça social, pela via da solidariedade humana, e no controle da pobreza, não discutindo os impactos da subalternidade na vida em sociedade. O objeto de intervenção assume alguns relevos, porém, sem perder seu cariz: a articulação harmoniosa entre o Estado e a sociedade para a garantia do desenvolvimento econômico e do bem-comum. Identifica-se aqui uma forte influência dos princípios da Igreja defendidos nas encíclicas papais, que determinam uma ação mais direta da Igreja na vida em sociedade.

O Serviço Social acompanha também o desenvolvimento e a expansão das organizações socioassistenciais. O assistente social é contratado para prestar serviços nessas organizações; é reconhecido e se reconhece como profissional da prática, identificando-se com as atividades demandadas pelos gestores, com as determinações presentes na organização que o contrata como profissional assalariado. Fundamentalmente, o assistente social é um profissional assalariado, contratado por essas organizações e submetido às suas regras. A atividade do profissional de Serviço Social, como tantas outras profissões, está submetida a um conjunto de determinações sociais inerentes ao trabalho na sociedade capitalista, quais sejam: “ [...] o trabalho assalariado, o controle da força de trabalho e a subordinação do conteúdo do trabalho aos objetivos e necessidades das entidades empregadoras" (COSTA, 2000, p. 37).

Uma observação importante é que, mesmo regulamentada como profissão de caráter liberal, majoritariamente os assistentes sociais trabalham como profissionais assalariados, prestando serviços em diferentes áreas, e como saúde, educação, 
assistência social, habitação, docência, entre outros, o que incide diretamente em sua autonomia e possibilidade de construir respostas profissionais. Ao assumir os objetivos da organização como os da própria profissão, parcela dos assistentes sociais demonstra a dificuldade em reconhecer suas atribuições e competências a partir dos instrumentos analíticos e interventivos presentes no exercício profissional. Explicando melhor: quando o trabalhador é contratado, espera-se dele que cumpra com as atribuições determinadas por seu empregador. Se o profissional não mantém um "distanciamento" analítico que Ihe possibilite examinar as condições em que o seu trabalho se efetiva, isso pode não só comprometer o que faz, mas também, a própria visibilidade e as implicações sociais desse fazer. Esse "distanciamento" é construído pelo profissional a partir de alguns pilares de sustentação: a identificação das demandas de atendimento e não apenas aquelas indicadas previamente pela organização; o conhecimento o poder local ${ }^{1}$; o conhecimento das condições objetivas em que o seu trabalho se realiza; a apropriação do assistente social acerca do projeto profissional; as condições objetivas de vida do usuário e o conhecimento da realidade social. Sem esse "distanciamento", o assistente social tende a identificar a organização como um bloco monolítico, sem qualquer possibilidade de alteração das condições de trabalho e serviços prestados.

Por seu lado, as organizações consomem não somente os saberes do profissional, mas também o produto do trabalho realizado, ou seja, o produto do trabalho também é determinado por quem o comprou. O que eu quero dizer? Na medida em que o assistente social é um trabalhador assalariado e identificado com os objetivos de quem o contratou, ele "espera" que seu empregador legitime aquilo que faz. Assim, o produto do trabalho é aquele que o empregador reconhece de acordo com as suas determinações. Nessa direção, o produto do trabalho do assistente social é avaliado por seu desempenho em cumprir as determinações da organização e não necessariamente pelo impacto de suas ações nas condições objetivas de vida do usuário. Ou seja, a construção do exercício profissional esbarra no limite da organização; o assistente social vai construindo e também reproduzindo as atividades que caracterizam o seu fazer profissional.

\footnotetext{
1 O poder local refere-se à esfera municipal. Para Daniel (1988), o poder local é compreendido como um lugar de exercício do poder "não se resume ao Estado - prefeitura e câmaras municipais, no nível local mas está disseminado em múltiplas instituições sociais" (DANIEL, 1988, p. 26).
} 
A partir do Movimento de Reconceituação - que demarca o início da renovação do Serviço Social no Brasil e na América Latina- o Serviço Social assenta-se em duas perspectivas para a construção do seu exercício profissional: a perspectiva conservadora e a perspectiva crítica.

A perspectiva conservadora fundamentada, principalmente, no positivismo e no estrutural-funcionalismo, referenda a função de controle e legitimação do poder dominante, sob a influência da Igreja, reforçando também a lógica do capital. O campo de atuação do assistente social é da mudança comportamental aliada às alterações no meio social. Esta direção aproxima-se daquela previamente estabelecida pela organização que contrata os serviços do assistente social. Reforça que os assistentes sociais assumam como do Serviço Social os objetivos da organização que o contrata como profissional assalariado. Nessa perspectiva, as demandas de atendimento, as atividades realizadas estão a serviço da manutenção da organização, cabendo o enquadramento dos usuários às regras e ao assistente social ser o intérprete privilegiado das determinações organizacionais.

A perspectiva crítica referenda o projeto societário da classe subalterna, bem como a necessária articulação entre o fazer profissional e o reconhecimento da realidade social como parte fundamental da intervenção. Essa perspectiva compreende que a prática profissional se constitui por meio de múltiplas determinações, no reconhecimento do caráter histórico e social presentes no exercício profissional; nas competências evidenciadas do campo teórico-metodológico, técnico-operativo e ético-político; a análise da realidade social; o reconhecimento das condições objetivas de vida do usuário; o caráter interventivo constitutivo da profissão. Para Silva e Silva (2002), um dos desafios vivenciados pelos assistentes sociais que compartilham desta matriz é "a busca de mediações analíticas capazes de dar conta da complexidade dos fenômenos sociais com os quais nos deparamos no cotidiano de nossa pratica profissional" (2002, p. 223). A partir da "entrada" da teoria marxista para o debate do Serviço Social, duas questões se destacam: a primeira está vinculada à concepção do Serviço Social como trabalho; a segunda é a importância do trato analítico como parte fundamental da dimensão interventiva. Ambas reforçam a discussão sobre a inserção profissional do assistente 
social nos espaços sócio-ocupacionais e sob quais condições o trabalho do assistente social é realizado. Assim,

[...] resgatar a prática do Serviço Social enquanto trabalho significa recuperar no âmbito das particularidades profissionais, aquelas forças e relações e seus sujeitos de classes. É revisitar a história do Serviço Social [...] (CARDOSO, et al, 1997, p. 28).

Mesmo apresentando um caráter contraditório, é possível encontrar, no mesmo campo de trabalho, profissionais atuando nas duas direções incorporadas a partir da renovação do Serviço Social, o que provoca, inclusive, conflitos entre os pares. Entendo que a direção construída por uma profissão é fruto da sua organização coletiva e é assimilada de forma heterogênea a partir do modo como os profissionais entendem e avaliam sua importância para a conformação do Serviço Social. A direção configura também a visibilidade, a consistência e a coerência teórica e argumentativa que o assistente social deve demonstrar quando realiza seu exercício profissional. O exercício profissional do assistente social ocorre mediante a explicitação dos elementos e condições socialmente determinadas que the garantem identidade, visibilidade, concreticidade e impulsionam sua direção.

Afirmar que a matéria-prima do trabalho do assistente social incide sobre as expressões da questão social e, fundamentalmente, sobre como elas são experienciadas, de forma singular, pelos usuários dos serviços prestados pelo assistente social é uma das formas de reconhecimento da perspectiva sócio-histórica e da afirmação de que o Serviço Social é trabalho. A questão social pode ser entendida como

[...] o conjunto das expressões das desigualdades da sociedade capitalista madura [...] o desenvolvimento nesta sociedade redunda uma enorme possibilidade de o homem ter acesso à natureza, à cultura, à ciência, enfim, desenvolver as forças produtivas do trabalho social [...] na sua contra-face, faz crescer a distância entre a concentração/ acumulação de capital e a produção crescente da miséria, da pauperização que atinge a maioria da população (IAMAMOTO, 1998, p. 27-28).

Inerente à sociedade capitalista, por meio das expressões da questão social, é possível identificar as desigualdades, a exclusão social vivenciada pela classe subalterna com a qual o assistente social lida cotidianamente. Yasbek (1999) analisa que 
[...] a subalternidade é aqui entendida como resultante direta das relações de poder na sociedade e se expressa em diferentes circunstâncias e condições da vida social, além da exploração do trabalho. (ex.: a condição do idoso, de mulher, de negro, etc) (1999, p. 95).

Mesmo vivendo sob condições adversas, a mesma classe apresenta vias de resistência a essa estrutura social quando reivindica sua inserção nos serviços mantidos pela rede de proteção social como uma das formas de enfrentamento para suprir suas necessidades. Nesse sentido, é essencial pensar a questão social não somente como cenário onde o exercício profissional do assistente social se materializa, mas também nela mesma e em suas expressões como dimensões constitutivas desse exercício. O objeto de intervenção do Serviço Social é historicamente determinado e sua análise deriva da perspectiva histórica e política assumida pelo assistente social a partir dos determinantes do projeto ético-político profissional. Dessa análise, decorre o exercício profissional cujo caminho e direcionamento pode ser o de assumir o objeto construído pela organização em que o assistente social atua como dele mesmo, como pode ser construído a partir das determinações decorrentes da correlação de forças entre conjuntura, contexto institucional, demandas do usuário, demandas organizacionais e o projeto ético-político construído pelos profissionais. Ainda assim, é preciso reforçar que o exercício profissional não ocorre de maneira tão linear: configura-se aí um embate entre aqueles profissionais que entendem que, para o Serviço Social construir respostas profissionais, é preciso fortalecer as atribuições determinadas pela organização e outros profissionais que entendem serem os caminhos para a construção de respostas profissionais indicados pelo projeto ético-político, pelos usuários e pela realidade social.

\section{O Serviço Social como Trabalho}

Como dito anteriormente, por meio da perspectiva consolidada por lamamoto (1998), considero que o Serviço Social é trabalho. Para entender tal modo de compreender e analisar a profissão, faz-se necessário conhecer o que é processo de trabalho e o que é trabalho. Marx diz que trabalho é "um processo entre o homem e a natureza, um processo em que o homem por sua própria ação media, regula e controla seu metabolismo com a natureza" (1983, p. 149). Ou seja, o homem utiliza-se de seus recursos físicos e intelectuais para, por meio do trabalho, apropriar-se da matéria-prima 
existente na natureza a fim de satisfazer suas necessidades. O trabalho é processado quando o homem interfere na natureza, modificando-a e modificando-se também. 0 trabalho humano apresenta outra característica que o torna singular: é a capacidade que o homem tem de projetá-lo mentalmente, prevendo inclusive os resultados que se pretende alcançar.

O trabalho assume papel de condicionador da existência humana, independentemente da sociedade que esteja sendo considerada. É ao trabalho que o homem tributa a razão de seu ser social, porque este propicia o arrancar das potencialidades naturais a seu serviço e, concomitantemente, conduz ao seu auto-desenvolvimento como espécie (PONTES, 2002, p. 61).

Ao projetar mentalmente seu trabalho, o homem cria também os processos de trabalho através dos quais o trabalho será construído. Assim, as atividades são consideradas por Marx os elementos mais simples do processo de trabalho.

Todo trabalhador, quando é contratado, recebe seu salário em troca de seu trabalho e do produto por ele produzido. O trabalho a ser desenvolvido é estabelecido por quem o contratou, cabendo ao trabalhador a sua execução. Com o assistente social não é diferente. Quando é contratado, recebe seu salário em troca da prestação de serviços para a qual ele coloca em movimento seus saberes para dar conta das questões apresentadas pela organização que o contratou e pelos usuários. Na execução do seu exercício profissional, o assistente social já "encontra" em seu local de trabalho, atividades previamente estabelecidas pelo empregador e/ou gestor. Tais atividades estão sujeitas à regulação que caracteriza o trabalho assalariado, regulação esta determinada por múltiplas determinações: o mercado de consumo, o produto que se quer produzir, os insumos, a oferta de mão-de-obra e o próprio salário. O assistente social é um profissional que executa programas e serviços na área socioassistencial, os quais, na maioria das vezes, já chegam com as atividades estabelecidas cabendo ao assistente social a sua execução.

Ao trabalhar na prestação de serviços, o assistente social realiza atividades que foram construídas por outros profissionais, não necessariamente assistentes sociais, o que compromete sua autonomia e determinação. Aqui está presente a discussão sobre a autonomia profissional, entendendo que essa autonomia é relativa. Por autonomia compreende-se a capacidade e a competência do profissional de tomar decisões, 
determinar seu exercício profissional, dar direção ao que faz. Essa autonomia é relativa na medida em que é mediada pelos objetivos e determinantes presentes na organização. Analisado dessa forma, não é o assistente social que organiza o seu exercício profissional, mas a própria organização para a qual presta serviço. O que o empregador espera é que ele cumpra suas obrigações sem questionamentos. Ao ser contratado para prestar serviços nas organizações, o assistente social é designado a desenvolver atividades previamente determinadas pelos gestores, cujo foco principal é a operacionalização das políticas públicas, a execução de programas, projetos e serviços determinados pelas diversas esferas governamentais, nas quais se inserem as atividades constitutivas do trabalho socioeducativo. Ainda nessa perspectiva, o assistente social trabalha em programas e projetos para os quais há repasse de recursos materiais, principalmente aqueles vinculados à área da assistência social e à área da saúde, dirigidos à população chamada de "baixa renda", ou seja, aquela que vive em condição de vulnerabilidade social, com dificuldade de acessar a rede de serviços socioassistenciais e manter, de forma autônoma, suas necessidades básicas. Ao recorrer ao assistente social, o usuário espera que o profissional seja capaz de construir uma resposta profissional que dê conta de suas necessidades, mesmo aquelas de caráter imediato como a ausência de alimentação, a dificuldade de acessar os serviços mais complexos na área de saúde pública, a busca por informação e orientação sobre a vida familiar. $O$ atendimento social é direcionado a realizar aquilo que o profissional entende que o usuário não tem condição de fazer autonomamente.

Inserido no mundo do trabalho como trabalhador assalariado, o profissional de Serviço Social, ao mesmo tempo em que sofre as consequencias da reestruturação produtiva, atua sobre ela quando em contato com os usuários. Essa reestruturação incide sobre o trabalho e as condições de trabalho do assistente social, ou seja, os profissionais trabalham em precárias condições de trabalho que também comprometem a autonomia do profissional.

Nessas condições, o assistente social realiza suas atribuições e de certa forma tem que remeter e corresponder aos interesses de quem mantém seu trabalho pois, a qualquer momento, à revelia do seu interesse, pode ser convidado a não mais trabalhar nesse local. 
Outro aspecto importante dessa condição de assalariamento é que não é permitida ao profissional a escolha da área de preferência para a realização do seu trabalho. 0 gestor, tanto da área pública como em outras áreas, determina onde o assistente social irá trabalhar, mesmo à revelia deste. A identificação com o que faz pode ou não vir depois.

Buscando entender como a condição de assalariamento incide sobre o exercício profissional do assistente social, identifica-se que há, por parte dos profissionais, o reconhecimento do descompasso entre aquilo que o profissional entende como necessário para o desenvolvimento do trabalho e o que é determinado pela organização que contrata o serviço, além da dificuldade de compatibilizar necessidades e recursos. 0 empregador determina a alocação dos recursos muitas vezes sem ouvir o profissional que lida diretamente com ele ou que reconhece as necessidades apresentadas pelos usuários.

Marx (1983) diz que quem compra a força de trabalho de um indivíduo social e o faz trabalhar consome não somente a força como também o produto, o resultado do que foi produzido. O que vem acontecendo com certa constância na área socioassistencial é que o assistente social tem sido cerceado em sua possibilidade de expressar a análise que realiza acerca do seu exercício profissional, de construir o modo como esse trabalho será realizado, o que dificulta inclusive a visualização do seu resultado.

O resultado esperado é aquele desejado pela organização e aquilo que ela reconhece como o que o profissional deve produzir. É possível dizer que o assistente social, quando acredita que o limite de sua ação é o limite proposto pela organização não se apropria do "produto" do que faz, nem se reconhece no que faz e não o reconhece. Por outro lado, a organização também não reconhece esse produto e tende a responsabilizar o profissional quando acontece algo errado ou quando o profissional não corresponde à sua expectativa.

O assistente social que não consegue ver o produto do seu trabalho não se valoriza, uma vez que não vê a importância do seu trabalho para a construção do produto final, mesmo quando, como no caso do Serviço Social, esse produto não é quantificável, como no trabalho produtivo. O profissional passa a questionar a validade de suas ações, atribuindo à condição genérica da profissão, as imprecisões que envolvem o exercício profissional, principalmente o como fazer. Ainda assim, embora não reconheça o produto 
e não se reconheça nele, o produto depende do seu trabalho e, de certa forma, lhe pertence, embora não fique com "sua parte".

Na medida em que não constrói os processos de trabalho e não reconhece as condições em que esse trabalho acontece, o profissional tende a realizá-lo de forma reificada, como labor, como um instrumento para manter viva a organização onde trabalha. Nesse contexto, o assistente social tem pouca mobilidade e flexibilidade para propor, ou mesmo alterar, o que Ihe foi determinado. A rotina é parte determinante no exercício profissional do assistente social. Por um lado, possibilita a organização e a avaliação das atividades desenvolvidas, bem como a identificação das atividades por parte dos usuários; mas, por outro, pode distanciar o profissional daquilo que ele faz, uma vez que mecaniza as ações. O fazer por repetição pode levar à desqualificação daquilo que é próprio do exercício profissional do assistente social: a necessária relação entre o pensar e a ação, entre a análise e a intervenção.

Marx (1983) diz que o trabalho é possibilidade de objetivação do homem, ou seja, através dele, ele constrói relações sociais e modifica a si mesmo e à realidade social onde vive. A relação da venda da força de trabalho impõe algumas determinações que ferem a autonomia profissional.

[...] este vínculo de assalariamento, ao mesmo tempo que é resultante das funções sociais atribuídas ao profissional, interdita suas ações às funções para as quais sua força de trabalho foi adquirida. Ao não se perceber como trabalhador assalariado, desprovido dos meios de produção, o assistente social pode acreditar na sua autonomia, que somente se explicita no plano jurídicoformal (GUERRA, 1995, p. 156).

Entendo que o espaço em que é possível identificar maior flexibilidade e autonomia está na relação que o assistente social estabelece com o usuário, uma vez que o modo como constrói essa relação pode proporcionar momentos de reflexão sobre o próprio fazer profissional e o significado social da profissão.

O significado social da profissão, por não ser quantificável, pode ficar subsumido ou não ser reconhecido no contexto sócio-organizacional. Está relacionado ao lugar ocupado pela profissão na sociedade e à necessidade de sua manutenção, uma vez que produz respostas profissionais que incidem na vida em sociedade e nas mediações estabelecidas, por meio das quais evidencia a característica analítica e o próprio exercício profissional. 
Tendo em vista que um dos prováveis resultados do trabalho do assistente social está relacionado aos impactos nas condições de vida do usuário, ele é pouco visível, pois dificilmente o trabalho desenvolvido é avaliado sob essa perspectiva. Outro aspecto importante é que o trabalho também abrange a capacidade criativa do homem de criá-lo e recriá-lo. Esse condicionante do trabalho ganha materialidade na construção das atividades que serão realizadas para se atingir os objetivos do trabalho do assistente social: contribuir para a melhoria das condições de vida dos usuários. Obviamente, o trabalho do assistente social compreende aspectos subjetivos que se relacionam ao modo como o assistente social entende a .profissão e aos múltiplos conhecimentos que estão presentes no exercício profissional.

[...] sendo o trabalho uma atividade do sujeito, ao realizar-se, aciona não só o acervo de conhecimentos, mas a herança social cultural acumulada, com suas marcas de classe, de gênero, etnia assim, como do processo de socialização vivido ao longo da história de vida, atualizando valores, preconceitos e sentimentos que aí foram moldados (IAMAMOTO, 1998, p. 103 - 104).

Vale o esclarecimento de que esse trabalho não é somente individual, apesar de realizado por indivíduos profissionais, é também coletivo. A identidade da profissão é construída pelo conjunto de profissionais que dão vida a essa profissão.

Para que o assistente social possa executar o seu exercício profissional, é preciso que ele analise também os meios de trabalho ou, como Marx (1983) diz, as coisas que o trabalhador coloca entre ele e o objeto, ou seja, a matéria-prima do trabalho, o que utiliza para guiar este trabalho. Cabe aqui entender o modo como os assistentes sociais organizam e realizam as atividades, suas atribuições no espaço sócio-organizacional, além de identificar as respostas profissionais construídas por eles. Dessa forma,

[...] analisar a profissão supõe abordar, simultaneamente, os modos de atuar e de pensar que foram por seus agentes incorporados, atribuindo visibilidade às bases teóricas assumidas pelo Serviço Social na leitura da sociedade e na construção de respostas à questão social (IAMAMOTO, 1998, p. 58).

Nesse caminho de análise, é preciso reconhecer como os assistentes sociais trabalham, quais os meios de trabalho que utilizam para colocar em movimento seu exercício profissional. Um dos primeiros meios identificados refere-se ao conhecimento das bases teórico-metodológicas, uma vez que, associados à questão da 
instrumentalidade e do conhecimento da realidade social podem contribuir para determinar os rumos do exercício e a construção das respostas profissionais.

[...] a objetivação do trabalho do assistente social, neste campo da prestação dos serviços, é composta por uma grande diversidade e volume de tarefas que evidenciam a capacidade desse profissional para lidar com uma gama heterogênea de demandas, derivadas da natureza e do modo de organização do trabalho (COSTA, 2000, p. 62).

O assistente social atua nessa correlação de forças: a organização determina o seu fazer e o profissional entende que pode exercer suas ações tomando também como referência o projeto da profissão. Ao colocar em movimentos seus saberes na realização do exercício profissional, o assistente social identifica o quanto é heterogêneo seu campo de trabalho, bem como as atividades que realiza. O campo da prestação de serviços requer do profissional que ele reconheça o lugar que ocupa no espaço sócioorganizacional. Esse posicionamento requer dele uma competência política, na defesa de idéias e ações que de fato favoreçam a construção de um projeto societário democrático. Explicita-se aqui a dimensão política presente no exercício profissional do assistente social, que se volta ao significado, ou seja,

[...] entender a prática profissional supõe inseri-la no jogo das relações das classes sociais e de seus mecanismos de poder econômico, político e cultural [...] a prática profissional tem um caráter essencialmente político: surge das próprias relações de poder presentes na sociedade [...] exige recursos teórico e um horizonte político para decifrar a dinâmica conjuntural, os sujeitos coletivos aí presentes e suas relações com a profissão (IAMAMOTO, 1998, p. 121 - 123 125).

Aqui se evidencia que, mesmo nesta condição de assalariamento, o assistente social também pode pensar e explanar suas ideias, estando aí explicitada sua relativa autonomia quanto à apresentação e operacionalização de propostas socioprofissionais. $A$ construção de respostas profissionais requer do profissional a articulação de conhecimentos referentes à realidade social e histórica e os conhecimentos advindos da interpretação do espaço sócio-organizacional no qual atua.

Identifico aqui a importância de se buscar articulação também com o projeto éticopolítico com o objetivo de construir respostas profissionais que não só justifiquem as ações desenvolvidas para a organização, mas (e também) que de fato evidenciem as demandas apresentadas pelos usuários. Cabe ressaltar o reconhecimento por parte do 
profissional das implicações do seu exercício profissional nas condições objetivas de vida do usuário, no espaço organizacional, o que significa reconhecer a importância do trabalho desenvolvido não por sua utilidade, mas, por seu significado social.

Um outro aspecto fundamental é que a organização não pode ser entendida apenas como um bloco monolítico, mas como um espaço contraditório onde se travam lutas pela operacionalização da prestação dos serviços socioassistenciais. Assim, ao mesmo tempo em que a organização determina o que é a atribuição do assistente social, o profissional pode também propor alternativas interventivas com base na análise das condições objetivas de vida do usuário, no conhecimento da rede de proteção e de atendimento socioassistencial e no conhecimento da realidade social. Negar a análise e as contradições presentes no espaço institucional compromete o exercício profissional, pois dificulta a possibilidade do próprio reconhecimento da organização como espaço de superação, de construção de respostas profissionais concretas. Sob essa perspectiva, ficam visíveis as dificuldades enfrentadas pelos profissionais em identificar no projeto profissional as possibilidades de articulação com o exercício profissional, uma vez que reconhecem no projeto da organização os parâmetros levados em consideração quando realizam suas atividades. Fica claro também que a adequação do trabalho social às exigências previamente estabelecidas pelos gestores dos projetos sociais é uma realidade e nem sempre o assistente social tem autonomia para interferir na questão.

\section{As dimensões constitutivas do exercício profissional do assistente social}

Tomando como referência a matriz crítica, o exercício profissional ocorre a partir de uma tripla dimensão: a interventiva, a analítica e a ética, que mantêm entre si uma relação de autonomia e interdependência, a saber:

- Dimensão Interventiva: aquela em que se explicita não somente a construção mas a efetivação das ações desenvolvidas pelo assistente social. Compreende intervenção propriamente dita, o conhecimento das tendências teórico-metodológicas, a instrumentalidade, os instrumentos técnico-operativos e os do campo das habilidades, os componentes éticos e os componentes políticos, o conhecimento das condições objetivas de vida do usuário e o reconhecimento da realidade social. Esta explicita o fazer profissional; dela emerge a existência, a materialidade e a concreticidade da profissão. 
Implica uma possibilidade do exercício profissional do assistente social, visto sob a perspectiva crítica, como superação de uma prática reiterativa. $\mathrm{O}$ atendimento às demandas postas pelos usuários exige do profissional a recriação constante do conhecimento e das mediações que norteiam a caminhada da teoria às práticas. É também na dimensão interventiva que ficam explicitados os instrumentos técnicooperativos, éticos e políticos presentes no exercício profissional do assistente social. A importância do trato analítico na construção da intervenção profissional é fundamental, uma vez que não há possibilidade de construção interventiva sem necessariamente ocorrer a análise dos fenômenos sociais, dos determinantes presentes na realidade social. Os assistentes sociais entendem que seu papel fundamental é posicionar-se, tomando como referência as necessidades apresentadas - via demanda de atendimento - pela classe subalterna, buscando consolidar uma atuação profissional cuja marca seja a defesa dos direitos sociais previstos na legislação social brasileira.

- Dimensão Investigativa: compreende a produção do conhecimento, a elaboração de pesquisas e os aspectos analíticos que dão suporte, qualificam e garantem a concretização da ação interventiva. Ou seja,

[...] é um suposto para a sistematização teórica e prática do exercício profissional, assim como para a definição de estratégias e o instrumental técnico que potencializam as formas de enfrentamento da desigualdade social (ABEPSS, 2007, p.67).

A dimensão investigativa não está circunscrita aos trabalhos acadêmicos, mas é expressão da qualificação do exercício profissional do assistente social.

- Dimensão ética: explicita os pressupostos estabelecidos no Código de Ética de 1993 e no projeto ético-político, destacando, principalmente, a forma como os assistentes sociais se apropriam deste conhecimento.

Essas dimensões, em complementaridade, favorecem a visibilidade do fazer profissional. São essas dimensões que consolidam a coerência, a consistência teórica e argumentativa e, para além disso, são as formas concretas do agir profissional. Acrescenta-se que o exercício profissional realizado sob essas dimensões amplia a discussão sobre a intervenção profissional, enfatizando a questão do compromisso e da competência, além de salientar a preocupação com o desenvolvimento teórico do Serviço Social. 
O assistente social entende que o exercício profissional realizado nos espaços sócioocupacionais não é exercido somente a partir da subordinação determinada quer seja pelo gestor, quer seja pelas políticas sociais, mas é também identificado como possibilidade de pensar e repensar esse exercício. Essa ambivalência repercute no exercício profissional na medida em que o assistente social reconhece o significado e os impactos sociais decorrentes do conjunto de ações desenvolvidas, além de conseguir perceber sua incidência na vida social. Entender essa questão colabora também para a identificação da visibilidade desse exercício e de sua importância na divisão sociotécnica do trabalho. A visibilidade está relacionada à identificação das atividades realizadas e do resultado produzido por elas, ou ainda, ao reconhecimento do assistente social sobre os impactos sociais do exercício profissional na vida em sociedade. Entendo, entretanto, que as condições em que o trabalho do assistente social se realiza colaboram para que a autonomia e o poder de decisão do profissional sejam restritos. Esse pequeno espaço favorece também a subordinação do profissional aos determinantes da organização e do gestor. A intervenção pressupõe que o profissional consiga planejar suas ações fundamentadas em referenciais que são constitutivos do exercício profissional. Partindo do princípio que o exercício profissional ocorre majoritariamente em espaços sócioorganizacionais, é preciso reconhecer as demandas apresentadas pelo gestor, ou seja, entender porque o assistente social é contratado, as atribuições estabelecidas naquele espaço, as interfaces com as atribuições identificadas com a área de atuação para assim compreender e analisar as demandas apresentadas pelo gestor. Aqui é preciso que o assistente social reconheça que as organizações, quando contratam um profissional, esperam que ele execute ações com resultados visíveis, o que é chamado no discurso das organizações de "impacto social". Ao mesmo tempo em que o profissional, até por sua condição de contrato de trabalho, é "obrigado" a responder às necessidades postas pela organização, cabe ao assistente social também " [...] reconhecer e conquistar novas e criativas alternativas de atuação, expressão das exigências históricas apresentadas aos profissionais pelo desenvolvimento das sociedades nacionais" (IAMAMOTO, 1992, p. 104).

Ao colocar em movimento seu acervo de conhecimentos, o assistente social identifica formas de reconhecimento das demandas profissionais, Uma delas é aquela 
indicada pelo próprio usuário dos serviços prestados e se relacionam com sua capacidade e autonomia para dar conta de suas necessidades básicas. Essas demandas podem ser reconhecidas por meio dos atendimentos realizados, do conhecimento das condições objetivas de vida do usuário, e do modo como vive e constrói relações. Outra forma de identificar demandas é a partir do próprio exercício profissional, da análise da realidade social, pela sistematização dos dados decorrentes das atividades desenvolvidas. Isso possibilitará ao assistente social reconhecer se de fato o exercício profissional está surtindo resultados, além de favorecer a implantação de processos avaliativos. Intervir significa também conhecer, planejar, executar e analisar ações profissionais do ponto de vista do próprio profissional, do ponto de vista da organização, do ponto de vista do usuário e da realidade social.

A intervenção engloba também o campo das habilidades profissionais. Essas habilidades são percebidas no modo e na direção que o assistente social dá ao seu exercício profissional. A postura assumida revela inclusive a compreensão acerca do protagonismo do usuário no trato interventivo. Reconhecer esse protagonismo pode ser uma via de superação do paternalismo que ainda se faz presente no exercício profissional de parcela dos assistentes sociais, como se os usuários precisassem ser ouvidos somente por suas queixas e não por sua capacidade e autonomia de decisão. Garantir condições de expressão aos usuários significa também defender seus interesses, explicitar seu projeto societário, a sua autopercepção acerca de suas condições objetivas de vida e de sua própria concepção de mundo. O reconhecimento dos resultados do trabalho interventivo é visível quando o assistente social analisa tanto as condições objetivas de vida do usuário, como os impactos deste na qualidade de vida do usuário. Esse conjunto de elementos e características do processo interventivo reforça a visão de que o exercício profissional não é autoexplicável ou ainda autoreferenciado, ou seja, "adquire seu sentido, descobre suas alternativas na história da sociedade da qual é parte" (IAMAMOTO, 1992, p. 120).

As condições para a concretização do exercício profissional decorrem também de diversas determinações: uma refere-se à análise de conjuntura como instrumento analítico que permite ao assistente social consubstanciar as relações existentes na realidade social, as demandas identificadas durante o processo interventivo e as 
implicações na situação-problema apresentada pelo usuário. A análise de conjuntura possibilita ao assistente social ampliar sua visão para além daquilo que pode ser visto como aparência, como um dos pontos de vista sobre uma dada situação. Esse recurso analítico torna factível o estabelecimento de relações entre o que o usuário apresenta sobre suas condições objetivas de vida, os determinantes organizacionais e a realidade social.

Uma das formas de materialização da intervenção é o trabalho socioeducativo. 0 reconhecimento do trabalho socioeducativo, por parte dos assistentes sociais, é controverso: uma parcela o reconhece associado à matriz crítica e outra como prerrogativa da prestação de serviços na área das políticas públicas. Este "reconhecimento" será apresentado a seguir.

\section{O trabalho socioeducativo como possibilidade interventiva}

A matriz crítica vem, ao longo dos últimos 20 anos, construindo um modo de estabelecer a intervenção, a partir de uma perspectiva denominada socioeducativa. A perspectiva vem se consolidando desde o final dos anos 1980, como uma marca característica da intervenção profissional. Tal perspectiva reforça que o trabalho realizado pelo assistente social tem como finalidade a consolidação das políticas sociais e públicas como políticas de direitos, cujo objetivo final é a proteção social e a garantia dos direitos sociais.

O trabalho socioeducativo tem sido utilizado tanto na abordagem individual, na abordagem grupal, bem como no reconhecimento do território. ${ }^{2}$ Sob essa perspectiva não há atuação preestabelecida, ou seja, a ação profissional é construída e reconstruída cotidianamente. É uma prática essencialmente histórica, em que está presente a busca constante do conhecimento. Instaura-se tendo como referência às relações de saber e poder presentes na sociedade e "reproduzidas" no espaço organizacional. O usuário é identificado como um dos protagonistas do processo interventivo e não como um receptor dos serviços estabelecidos previamente pelo poder público ou mesmo pelas organizações nas quais o assistente social é contratado. Caracteriza-se por consolidar a

\footnotetext{
2 Na perspectiva da implantação do Sistema Único da Assistência Social - ver Política Nacional da Assistência Social.
} 
visão da educação popular, em que o profissional atua tomando como referência os modos de vida da população usuária, possibilitando a realização de uma prática crítica, que se configura na sua concreticidade, criticidade e teleologia. Na contemporaneidade, o trabalho socioeducativo tem sido amplamente utilizado como referência metodológica para o trabalho dirigido à proteção sóciofamiliar, "reflete uma proposta de prática vinculada aos interesses da população, voltada para a perspectiva da transformação social [...] numa busca de superação do paternalismo" (SILVA; SILVA, 2002, p. 175 - 177).

Na perspectiva socioeducativa, o atendimento individual é operacionalizado a partir de uma base metodológica que tem sido construída e reconhecida, articulada ao projeto de ruptura. $^{3}$ À abordagem socioeducativa foi construída como um diferencial à abordagem psicossocial. Requer do assistente social uma leitura fundamentada do projeto éticopolítico, da realidade social constitutiva do exercício profissional. Demarca uma direção social para o exercício profissional, qual seja, a de consolidar o projeto éticopolítico. Essa abordagem estabelece a necessidade do assistente social reconhecer as demandas postas para o atendimento social e a formulação e a construção das respostas profissionais de caráter crítico-analítico, articuladas as condições objetivas de vida do usuário e a realidade social.

No atendimento individual, o fundamento teórico é a matriz crítica, cuja base é o marxismo. Para sua operacionalização é preciso entender analiticamente as condições objetivas de vida do usuário, mediante o conhecimento do modo como os usuários estabelecem suas relações cotidianas, como se reconhece como sujeito que é, ao mesmo, tempo individual e coletivo. O trabalho socioeducativo demarca, na relação assistente social - usuário, a ultrapassagem da visão de problema individual para demandas de atendimento, ou seja, amplia-se a visão, articulando-se os problemas apresentados pelo usuário, a realidade social vivenciada e os limites da organização onde o assistente social presta serviço. É um trabalho voltado à intervenção que reflete: as demandas identificadas para atendimento; os procedimentos adotados pelo assistente social; o diagnóstico preliminar da situação, em que são identificadas as determinações presentes no atendimento; a relação estabelecida entre o assistente social e o usuário e o

\footnotetext{
${ }^{3}$ Denominação dada ao projeto profissional que tem por base a matriz crítica fundamentada na teoria social crítica.
} 
reconhecimento das contradições presentes no espaço organizacional. Um dos principais ganhos do trabalho socioeducativo é que, no processo metodológico, o usuário é o sujeito, reconhecido como protagonista dessa relação. Nessa perspectiva, o assistente social deve ser capaz de democratizar informações e fomentar a tomada de decisão por parte do usuário. Os serviços prestados não são vistos como favor, mas, como um direito que será acessado para suprir as necessidades apresentadas pelo usuário e/ ou identificadas pelo assistente social.

A abordagem grupal segue também a perspectiva socioeducativa. Geralmente, quando o assistente social trabalha em programas de repasse de renda, é solicitado que o acompanhamento seja realizado a partir desta abordagem. Para tanto, é necessário que seja enfocado o reconhecimento dos sujeitos que participam do grupo: quem são; quais as condições objetivas de vida; quais os objetivos para participar do grupo. É um trabalho que explicita a identificação de lideranças; a discussão do significado da participação; a análise das atividades desenvolvidas; o perfil dos participantes; a relação entre os protagonistas e as demandas apresentadas, e, o papel do coordenador e da coordenação, entre outros.

O trabalho socioeducativo refere-se também à possibilidade do profissional refletir sobre os resultados alcançados com o exercício profissional. Aqui, ganham relevo as implicações do exercício profissional na vida do usuário, a compreensão quanto às informações e orientações obtidas, além da necessidade do assistente social repensar constantemente, a construção de estratégias de intervenção em consonância com as contradições presentes na realidade social. A realização do trabalho socioeducativo implica que os limites identificados no espaço sócio-ocupacional, lócus do trabalho do assistente social, devem ser analisados não como uma barreira intransponível mas, como um indicativo para a construção das respostas profissionais. Atuar nessa perspectiva requer um profissional cuja formação explicite sua consistência teórica, metodológica, ética e argumentativa. No trabalho socioeducativo, existe ainda a necessidade do assistente social analisar o seu exercício profissional também pelo resultado alcançado. Um dos elementos que pode ser facilitador desse processo refere-se ao impacto social desse conjunto de ações na vida do usuário e as implicações na melhoria de sua construção relacional. O assistente social utiliza-se de instrumentos analíticos e técnico- 
operativos a fim de entender e analisar as relações estabelecidas entre o que é determinado pela organização, pelo programa e/ou projeto, pelo próprio profissional e pelo usuário. Tal abordagem pressupõe que o planejamento das atividades seja realizado de forma conjunta, envolvendo o profissional e o usuário.

O trabalho socioeducativo perpassa necessariamente pela compreensão que o assistente social tem do seu exercício profissional, uma vez que é reconhecido como o profissional que atua no campo das políticas sociais, campo da realização de programas assistenciais, vinculados ou não ao Estado. Trabalha a partir da prática interventiva, referenciando o projeto éticopolítico, a formação profissional, a dimensão ideológica e política. A proposta metodológica de ruptura fundamenta-se por meio das categorias teóricas, fundamentadas na dialética marxista: Estado; instituições, política social; transformação social; dimensão política; classe social; trabalho; mediação; história; e proposta de ação.

A proposta de ação agrega três dimensões, em articulação com a prática interventiva: acadêmica, organizativa, intervenção na realidade social. O que caracteriza esta prática interventiva é o compromisso com a classe subalterna e o esforço por romper com a proposta conservadora ainda presente no exercício profissional do assistente social.

A proposta caminha por romper com esquemas preestabelecidos e normatizados como a única estratégia de construção da ação profissional. Indica a necessidade de buscar compreender os determinantes presentes na ação desenvolvida, quais sejam: o espaço organizacional; o conhecimento das demandas; o conhecimento da realidade social do usuário da ação; o conhecimento específico da área de atuação; o conhecimento das tendências teórico-metodológicas presentes na ação profissional do assistente social; o Código de Ética e o projeto profissional. A operacionalização dessa proposta pressupõe reconhecer o usuário como sujeito privilegiado da ação profissional.

Por se tratar de uma construção de caráter metodológico, entende-se ser necessário que o assistente social tenha uma base teórica sólida que o possibilite construir uma prática direcionada pelo projeto ético-político da profissão. Esse modo de entender a intervenção favorece a construção do conhecimento de forma contínua e por aproximações sucessivas. A consolidação do exercício profissional como prática crítica é 
um processo de construção permanente, cujo limite é indicado pelo próprio movimento da realidade social.

O que venho observando é que, no trabalho dentro das organizações, as atividades desenvolvidas por meio da abordagem socioeducativa assumem outra direção: a da conformação do usuário aos determinantes institucionais, isto é, o assistente social é o profissional que vem respondendo pela execução de programas e projetos apensos a área social. Nessa execução, é responsável por realizar a inscrição e o acompanhamento social das famílias; identificar a adesão das famílias às atividades propostas, avaliar os resultados obtidos e efetivar o desligamento. Tendo em vista as características da gestão das políticas públicas, tal processo já está previamente estabelecido por quem planejou os serviços e, nesse momento, na maioria das vezes, o assistente social não participa. Assim, mesmo não concordando com as determinações, é obrigado a cumpri-las, muitas vezes sem a possibilidade de questionamentos. Em algumas situações participa do planejamento das ações referentes ao acompanhamento social, mas, poucas vezes o usuário é chamado a participar. As ações são de caráter regulador, levando freqüentemente o usuário a se travestir de "vítima das circunstâncias", como uma forma de acessar os programas da referida área. Assim, vincula-se à matriz a conservadora, onde o profissional é um executor e o usuário é o receptor de serviços, sendo exigido para sua permanência no serviço, o cumprimento de atividades e metas previstas anteriormente pelos gestores do programa. Essa contradição explicita diferentes formas de reconhecimento do trabalho socioeducativo, além de favorecer o debate profissional em torno do papel desempenhado pelos assistentes sociais no fortalecimento das políticas sociais, em especial, da assistência social.

\section{Considerações Finais}

Nos anos 1990, o Serviço Social vê fortalecida sua presença como profissão interventiva na discussão e aprovação de legislação no campo social: o Estatuto da Criança e do Adolescente, Lei Orgânica da Assistência Social; no campo específico da profissão: o Código de Ética e a Lei de Regulamentação da Profissão. Nos anos 2000, os assistentes sociais participam ativamente da elaboração e promulgação do Estatuto do Idoso; sobre a legislação de acessibilidade de pessoas com deficiência, entre outras. Em 
decorrência da legislação, também é responsável pela implantação e a implementação das políticas sociais, não somente nos aspectos que decorrem da operacionalização de serviços, com ênfase na implantação dos conselhos, na construção dos planos municipais de assistência e mais recentemente, contribuindo na elaboração da metodologia participativa que envolve a construção dos planos diretores dos municípios.

Ainda na área da assistência social, vem colaborando com a implantação do SUAS Sistema Único da Assistência Social e é considerado sujeito privilegiado desse processo, principalmente por seu acúmulo de conhecimento na área.

Alguns avanços ainda são esperados principalmente aqueles que estão intrinsecamente relacionados ao trabalho direto com os usuários, na abordagem individual e no trabalho socioeducativo. Entendo que a resposta profissional para essa questão não é somente "instrumental-operativa" (NETTO, 1996, p. 123), mas de caráter analítico e interventivo. Compartilho da idéia, defendida por Netto (1996), de quem erra na análise, erra na intervenção. Portanto, à dimensão interventiva, pressupõe uma dimensão analítica e ética.

Considero necessário o aprofundamento do conhecimento acerca do trabalho socioeducativo, bem como o modo com tem sido concretizado nos espaços sócioocupacionais, uma vez que é reconhecido como uma das estratégias dos gestores públicos para o acompanhamento das famílias inseridas nos programas vinculados à rede socioassistencial.

\section{Referências}

CARDOSO, I. C. da C., et al. Proposta Básica para o projeto de formação profissional novos subsídios para o debate. Cadernos ABESS. Formação Profissional: trajetórias e desafios. São Paulo: ABESS, n. 7, p. 15 - 57, 1997.

CRESS. Legislação Brasileira para o SS: coletânea de leis, decretos e regulamentos para instrumentação do assistente social. CRESS SP. São Paulo: O Conselho, 2007.

COSTA, M. D. H. da. O trabalho nos serviços de saúde e a inserção dos (as) assistentes sociais. Revista Serviço Social e Sociedade, São Paulo: Cortez, n. 62, p. 35 - 72, 2000.

DANIEL, C.. Poder Local no Brasil urbano. Espaço \& Debates. Revista de Estudos Regionais e Urbanos. São Paulo, NERU, ano VII, n. 24, p. 26 - 39, 1988. 
ABESS. Diretrizes Gerais para o curso de Serviço Social (com base no currículo mínimo aprovado em Assembléia Geral Extraordinária de 08/ novembro/ 1996). Formação Profissional: trajetórias e desafios. São Paulo: Cortez, Cadernos ABESS, n. 07, p. 58 - 76, 1997.

GUERRA, Y.. A instrumentalidade do Serviço Social. São Paulo: Cortez, 1995.

IAMAMOTO, M. V. \& CARVALHO, R.. Relações sociais e Serviço Social no Brasil: esboço de uma interpretação histórico-metodológica. 2. ed. São Paulo: Cortez, 1983.

IAMAMOTO, M. V. O Serviço Social na contemporaneidade: trabalho e formação profissional. São Paulo: Cortez, 1998. . Renovação e Conservadorismo no Serviço Social: ensaios críticos. São Paulo:

Cortez, 1992.

MARX, K. O processo de produção do capital. In. O Capital - crítica da economia política. São Paulo: Abril Cultural, 1983. capítulo V, p. $149-163$.

NETTO, J. P. Transformações societárias e Serviço Social: notas para uma análise prospectiva da profissão no Brasil. Revista Serviço Social e Sociedade, São Paulo, n 50, ano XVII, p. 87 - 132, 1996.

PONTES, R. N.. Mediação e Serviço Social. 3. ed., São Paulo: Cortez, 2002

SILVA E SILVA, M. O. . O Serviço Social e o popular: resgate teório-metodológico do projeto profissional de ruptura. 2. ed, São Paulo: Cortez, 2002.

TORRES, M. M.. A coruja e o camelo: a interlocução construída pelos assistentes sociais com as tendências teórico-metodológicas do Serviço Social. 2006. $414 \mathrm{f}$ Tese (Doutorado em Serviço Social) - Programa de Serviço Social. Pontifícia Universidade Católica de São Paulo, 2006.

YASBEK, M. C. O Serviço Social como especialização do trabalho coletivo. Capacitação em Serviço Social e política social: módulo 2: Crise contemporânea, questão social e Serviço Social. Brasília: CEAD, p. 89 - 99, 1999. 